\title{
Workplace Opportunities for Women Employed in Core Mining Activities
}

\author{
Dr. Doret Botha \\ North-West University, South Africa \\ Doret.Botha@nwu.ac.za \\ Prof Freek Cronjé \\ North-West University, South Africa \\ Freek.Cronje@nwu.ac.za
}

Doi:10.5901/mjss.2014.v5n23p1914

\begin{abstract}
Mining as occupation in South Africa was traditionally reserved for men only and mining law prohibited women from being employed in operations underground. In South Africa, new mining legislation aimed to rectify previous inequalities and disadvantages in the mining sector and specifically provides for the inclusion of women in core mining activities. Although women's participation in the industry has slowly risen since the introduction of the Mining Charter and related government equity legislation, women are still at the periphery of the industry. Furthermore, white women continue to dominate the professional positions in mining and black women tend to engage mostly in manual work and artisanal mining. This research aimed to determine perceptions regarding workplace opportunities for women working in core mining positions. Findings are being drawn from empirical work undertaken at a platinum, phosphor and copper mine. The quantitative and qualitative research paradigms were used. It is evident from the research that specific attention should be given to the career development and progression of women working in the core business of mines. Practical recommendations are made which could be implemented and used by mining companies to overcome some of these issues.
\end{abstract}

Keywords: Core mining activities, women in mining, workplace opportunities, sustainable deployment, mining industry

\section{Introduction}

Mining as occupation in South Africa was traditionally reserved for men only and mining law prohibited women from being employed in operations underground. Women were also constrained by tradition that prevented them from working in surface mines or in surface occupations (Moyo, 2010:61).

The new democratic government of South Africa adopted a number of strategies to open up the mining sector to Historically Disadvantages South Africans (HDSAs), which include women, as part of its economic empowerment policy. The Constitution of the Republic of South Africa was implemented and laid the foundation for a democratic society. Furthermore, a comprehensive reformation of the South African labour policy took place. Various acts were introduced and amended to further transform the total labour industry, including the mining sector. New mining legislation (the Mineral and Petroleum Resources Development Act (28 of 2002) and the Broad-based Socio-economic Empowerment Charter), was also introduced and not only prohibits the exclusion of women, but also requires from companies to actively change the demographic profile of the company and to employ women in core mining activities. "Women employed in core mining activities' implies that women should hold positions equivalent to that of men, in other words, fill positions in mining that includes, among other activities, mining, metallurgy, engineering and geology (Harmony Gold Mining Company, 2008, p. 32). Amendments to the mining charter (launched in 2010) aimed to further promote women's participation in the mining industry and provided set targets for HDSAs participation, which include women, which should be reached by March 2015.

Women's participation in the industry has slowly risen since the introduction of the Mining Charter and related government equity legislation. In 2001, 20000 women were employed in the mining sector and in 2012, 52000 (South African Institute of Race Relations, 2012:232). This indicates a significant change of 160\% in female employment. However, women are still at the periphery of the industry as reflected in the low presentation of women on the boards of directors of mining companies as well as in senior management and supervisory positions (Moyo, 2010:61; DoL, 2012:40-46). White women also continue to dominate the professional positions in mining and black women tend to 
engage mostly in manual work and artisanal mining (Hermanus, 2007:3).

Although well intended, the establishment of gender equality in the male-dominant mining sector remains one of the biggest equity challenges in the country and numerous problems accompany the deployment of women in the core business of mines. To include and promote women's participation in the mining industry, and specifically in core mining activities, was and still is not an easy task at hand for mining companies. Mining companies continuously struggle to reach the targets set by the Mining Charter and run the risk of losing their mining licenses to operate if they do not meet the requirements. On the one hand, mining companies had and still have to find able and capable women to employ in core mining positions and on the other hand, women do not want to be seen as 'quota appointments', but want to be taken seriously in the workplace.

Appropriately, the purpose of the article is to firstly, highlight barriers in career development and progression for women employed in core mining activities according to the literature, secondly, to reveal issues regarding workplace opportunities for women employed in core mining positions as identified in the empirical research and thirdly, to provide recommendations which could be implemented and used by mining companies to overcome some of these issues. Findings are being drawn from empirical work undertaken at a platinum, phosphor and copper mine in South Africa.

\section{Career Development and Progression of Women in Mining: A Global View}

Globally, one of the main challenges that women are facing in the mining industry is insufficient professional and career development, which include poor mentoring systems and career paths.

In America, in the mid-1990s, Suzanne Tallichet investigated the world of women miners by spending several months in a West Virginia coal mining community (Mercier, cited in Lahiri-Dutt, 2011:33). She found that women still faced tremendous challenges in the mining environment. The research also indicated that women were prevented from moving out of lower-paying strenuous jobs to more skilled positions. Women were not allowed to learn new skills to operate machinery or were not trained when they attained such skilled positions (Mercier, cited in Lahiri-Dutt, 2011:42) .

A recent study conducted by Women in Mining Canada in 2010 (2010:9) on the current status of women in mining and exploration revealed that women were still facing major challenges to being employed and accommodated in the mining environment. Women also indicated that they experienced difficulties to advance in their careers and fill senior positions in the mining industry. Specifically, senior management and executive positions are the most difficult to fill, followed by the chief executive officer, middle management and supervisory roles. The following aspects were identified as gender-related barriers that inhibit the advancement of women in the industry (Women in Mining Canada, 2010:9):

- Male-dominated work culture;

- Misperceptions of women's abilities;

- Unsupportive work cultures and relationships with supervisors;

- Absence of mentors and role models in senior roles;

- Insufficient professional and career development;

- Personal characteristics such as confidence, assertiveness and low self-esteem.

The research also revealed an urgent need for support from persons in supervisory or leadership roles as well as professional development/training and mentorship programmes.

In Australia, in 1998, Pattenden was commissioned by the AusIMM's WIMNet (Australian Institution of Mining and Metallurgy Women in Mining Network) to undertake in-depth research on employment barriers inhibiting female participation in the industry. Among many challenges, the research revealed the following career development barriers for female technical professionals (Pattenden, 1998:9):

- Poor implementation and monitoring of Equal Employment Opportunity (EEO) policies;

- Issues related to the professional development of women, including challenges of male-female mentoring relationships;

- Women believing they must out-perform men in order to be regarded equally;

- Salary inequity;

- Female exclusion from male-dominated professional and social networks.

In 2011, the Australian government partnered with the Minerals Council of Australia to produce three research reports examining the attitudes and experiences of women regarding working in the minerals industry. The research reports identified key factors for the minerals industry to consider in order to enhance the participation of women in the industry (Minerals Council of Australia, 2011:2). Among others, a gender-inclusive environment is promoted, including structured mentoring programmes for women and career opportunities that enable people to transition in and out of 
employment in the industry.

In Papua New Guinea, Macintyre (cited in Lahiri-Dutt, 2011:26) conducted research on the experiences of women in the workplace over a period of eight years. From the findings it was also evident that almost all women experienced difficulties in gaining promotion.

In southern Africa, Moyo (2010:61) conducted research to assess the participation of women in mining and the underlying factors which limit their participation. Among many factors, the study revealed that skills development and training are not freely available and that women are seldom specifically targeted for bursaries and scholarships. This view is also supported by the findings of this research.

As indicated in the Introduction, women's participation in the South African mining industry has slowly risen since the introduction of the Mining Charter and related government equity legislation. However, women are still at the periphery of the industry and most women are employed in supportive functions and only a few held core management positions which are largely filled by white women. Also see Table 1.

Table 1: Workforce profile population distribution of the mining and quarrying sector, 2011-2012

\begin{tabular}{|c|c|c|c|c|c|c|c|c|c|c|}
\hline \multicolumn{4}{|c|}{ Male } & \multicolumn{4}{|c|}{ Female } & \multicolumn{2}{|c|}{ Foreign national } & Total \\
\hline A & C & I & W & A & C & I & W & M & $\mathrm{F}$ & $\mathrm{T}$ \\
\hline $14.9 \%$ & $1.8 \%$ & $2.1 \%$ & $66.1 \%$ & $3.2 \%$ & $0.5 \%$ & $0.6 \%$ & $7.3 \%$ & $3.5 \%$ & $0.1 \%$ & $100 \%$ \\
\hline \multicolumn{11}{|c|}{ Workforce profile at the senior management level by race and gender } \\
\hline \multicolumn{4}{|c|}{ Male } & \multicolumn{4}{|c|}{\begin{tabular}{c|c} 
Female & \\
\end{tabular}} & \multicolumn{2}{|c|}{ Foreign National } & Total \\
\hline$A$ & C & I & W & A & $\mathrm{C}$ & 1 & W & M & $\mathrm{F}$ & $\mathrm{T}$ \\
\hline $15.4 \%$ & $2.2 \%$ & $3.2 \%$ & $60.9 \%$ & $3.4 \%$ & $0.6 \%$ & $1.2 \%$ & $9.3 \%$ & $3.4 \%$ & $0.3 \%$ & $100 \%$ \\
\hline \multicolumn{11}{|c|}{ Workforce profile at the professionally qualified level by race and gender } \\
\hline \multicolumn{4}{|c|}{ Male } & \multicolumn{4}{|c|}{ Female } & \multicolumn{2}{|c|}{ Foreign National } & Total \\
\hline A & C & I & W & A & C & I & W & M & $\mathrm{F}$ & $\mathrm{T}$ \\
\hline $22.7 \%$ & $2.6 \%$ & $2.7 \%$ & $48.4 \%$ & $7.5 \%$ & $1.0 \%$ & $1.3 \%$ & $11.2 \%$ & $2.2 \%$ & $0.4 \%$ & $100 \%$ \\
\hline \multicolumn{11}{|c|}{ Workforce profile at the skilled level by race and gender } \\
\hline \multicolumn{4}{|c|}{ Male } & \multicolumn{4}{|c|}{ Female } & \multicolumn{2}{|c|}{ Foreign National } & Total \\
\hline A & $\mathrm{C}$ & I & W & A & $\mathrm{C}$ & I & W & M & $\mathrm{F}$ & $\mathrm{T}$ \\
\hline $42.9 \%$ & $3.6 \%$ & $0.8 \%$ & $31.6 \%$ & $8.2 \%$ & $1.0 \%$ & $0.5 \%$ & $6.7 \%$ & $4.5 \%$ & $0.1 \%$ & $100 \%$ \\
\hline
\end{tabular}

A: African; C: Coloured; I: Indian; W: White; T: Total

Source: Table adapted by author (based on DoL, 2012:40-46)

From the above it is clear that despite social and cultural differences as well as mining activities conducted in the various countries and continents, women across the globe experience challenges with regard to career development and progression in the industry.

\section{Barriers in Career Development and Progression}

Stead and Watson (2010:110) idenified role conflict, gender stereotyping and the glass ceiling effects as barriers that could affect women's career development.

\subsection{Role conflict}

Women's dual involvement in home and paid work and the demands thereof could lead to stress, role conflict and role overload. Role conflict exists when an individual is confronted by divergent role expectations, in other words, the individual finds that compliance with one role requirement makes it difficult to comply with another (Robbins et al., 2009:222). Role overload is experienced when employees must do more than time permits (Robbins et al., 2009:222). Dual-career women often do not have time to perform the tasks required by the different roles (for example home, work and personal). In addition, organisations put increased demands on female managers who already face demanding and challenging jobs. This may result in compromising of some degree in one or more roles. This could have an impact on their work, home or personal health (Stead and Watson, 2010:118). 


\subsection{Gender stereotyping}

Some scientists believe that women's career development is inhibited by discrimination and sexual harassment and cultural constraints such as occupational gender stereotypes and gender socialisation in addition to their "motherhood role" (Fitzgerald \& Netz, cited in Stead and Watson, 2010:118). According to Wharton (2006:31), "socialisation refers to the processes through which individuals take on gendered qualities and characteristics and acquire a sense of self". Through socialisation people learn what could be expected of men and women. Archer and Lloyd (2002:19) define stereotypes as "the shared beliefs that people hold about a group of people such as an ethnic group or people in a particular occupation" and gender stereotypes as "the beliefs people hold about members of the categories man or women". Eagly (cited in Archer and Lloyd, 2002:24) postulates that "gender roles and stereotypes held in a society at any one point in time are rooted, not primarily in the society's cultural tradition, but more importantly in the society's contemporary division of labour between the sexes". This means that women and men are viewed as suited for specific social roles that they typically apply. This is known as the social role theory and suggests that if roles change, the stereotypes will also change. Although there is evidence of a decline in gender segregation of occupations nowadays, mostly due to equity legislation and policies, much still needs to be done to reduce gender barriers and to remove traditional stereotypes to ensure employment of women in all occupations (including occupations traditionally reserved for men, such as mining) and at all levels (including senior and top management positions).

\subsection{Glass ceiling}

Glass ceiling' is a term used to describe why only a few women are appointed in leadership positions, why they do not advance as rapidly as their male counterparts in the hierarchical structure of the organisation and why they tend to face more stringent promotion requirements than men. It therefore symbolises a barrier to entry into top management (Stead and Watson, 2010:119). According to Lorber (2010:34), the concept of a glass ceiling suggests that women have the motivational ambition as well as the capacity to be employed in leadership positions. However, men continued to dominate high-prestige occupations in the Western world (Archer and Lloyd, 2002:182). Stead and Watson (2010:120) point to the following explanations for the glass ceiling phenomenon:

- The belief exists that it is risky to promote women to senior positions;

- Men in high-ranking positions often believe that women are not as competent, intelligent and capable as their male counterparts;

- A perception exists that women cannot function effectively in the tough and competitive business world;

- The belief exists that motherhood tends to distract and divert women from their careers;

- Men often feel uncomfortable sharing power with women;

- The perception exists that corporate power stays with men because those in authority promote in their own image;

- The belief exists that women do not have the appropriate attitudes, behaviours, skills, education and training for managerial and professional jobs;

- The lack of mentors and sponsors;

- Structural and systemic discrimination exist due to organisational policies and practices.

\section{Legislative Requirements}

In South Africa, the legislative framework to promote and enhance learning and skills development is provided by the South African Qualifications Authority (SAQA), the Skills Development Act (97 of 1998) and the Employment Equity Act (55 of 1998) (Pons and Deale, 2010: ch. 19, p. 4). Human resource development is also enforced by the revised Mining Charter and according to the requirements of the revised SLP, mining companies are obliged to provide a detailed skills development plan outlining the "intent to offer employees development of requisite skills in respect of learnerships, bursaries (of core and critical skills), artisans, ABET training (level I, II, III, IV and NQF 1) and other training initiatives" (RSA, 2010b:8). Furthermore, mining companies should provide career development matrices of each discipline, develop individual development plans for employees and identify a talent pool to be fast-tracked in line with the needs (RSA, 2010b:10). Mining companies should also provide a mentorship plan for employees as well as a bursary and internship plan. All these plans should indicate the targets, timeframes and budgets of how the plans will be implemented (RSA, 2010b:13). 


\section{Research Methodology}

\subsection{Research approach}

A mix-method research design was followed by applying a quantitative and qualitative research approach.

\subsection{Measures}

\subsubsection{Research participants}

The research setting was limited to the following three mines: a platinum mine (underground), a copper mine (underground) and a phosphate mine (open-cast). The mines were selected on an availability basis (convenient sampling).

For the purpose of quantitative research, the study population consisted of an availability sample of management as well as male and female employees working in core mining activities of the three mines. In total, 156 responses were received - 68 from the Copper mine, 38 from the Platinum mine and 50 from the Phosphate mine.

Purposive or judgemental sampling was used to select participants for qualitative research, in other words basic individual interviewing as well as group interviews. At all three mines, the human resource officer targeted with women in mining was responsible for selecting participants to be interviewed as well as scheduling the interviews. In total, 12 individual interviews and 19 group interviews (69 participants) were conducted. The researcher aimed to gain information from various operations; therefore, the participants selected varied from various categories of employment and mining disciplines.

\subsubsection{Measuring instruments}

Quantitative data were collected by means of a structured questionnaire. Qualitative data were collected by means of individual interviews, group interviews and direct observation. Both the individual interviews and the group interviews were semi-structured; an interview guide was utilised. Observation was used complementary to the interview surveys and provided insights into variables that have an impact on women working in the core activities of the mines. Data collected by means of semi-structured and group interviews were audio and video recorded and written notes were taken.

In addition, the researcher attended two Women in Mining Conferences held in 2010 and 2011. The conferences highlighted and outlined barriers and challenges facing the mining industry in respect of successfully bringing women into the mining sector. Both conferences were concluded with an interactive workshop. The researcher took detailed notes during the conferences.

The qualitative approach supported the quantitative approach and aimed to provide more reliable results because the researcher could ask probing questions to the participants and by so doing avoid misunderstanding of questions and gain a better insight into the phenomenon of interest. In addition, the researcher could gain a deep understanding of the variables that have an impact on women in the mining sector.

\subsubsection{Research procedure}

The researcher formally requested permission from mine management to conduct research at the three mining companies. After permission was granted, a formal appointment was scheduled with mine management to explain the nature and extent of the research. In each research setting (mines), a contact person (human resource officer targeted with women in mining) was allocated to the researcher to provide the necessary assistance and support during the research, which included the following: distributing and collecting of the quantitative questionnaires, selecting appropriate participants for the individual interviews as well as group interviews, scheduling interviews and organising the underground field trip as well as visits to surface mining operations. Most of the individual interviews and group interviews were scheduled between shifts in order not to interfere with the work responsibilities of the participants. Ethical considerations as recommended by Babbie and Mouton (2011:520) were taken into account while conducting the research. 


\subsubsection{Data analysis}

Quantitative data obtained by questionnaires were analysed with the support and assistance of the Statistic Consultation Service of North-West University. The statistical software program SPSS 21.0 for Windows was used to analyse the data. Firstly, descriptive statistics and frequencies are presented, differentially in terms of the three mines included in the study. Descriptive statistics were reported per statement as mean and standard deviation. The benchmark (ideal) in terms of responses for every statement would be 4 , which indicates that compliance with the specific statement is satisfactory, except for a small number of reversed statements. Ratings of 2.5 and lower were regarded as 'low' and indicate that compliance with the specific statement is none or very limited. The opposite is applicable for reversed statements. Secondly, a factor analysis was conducted to explore the factorial structure of the section; these findings are also reported and discussed. Thirdly, effect sizes were measured. Because an availability sample was used, $p$-values were not relevant and differences between means were examined for practical significance with effect sizes. Lastly, qualitative data obtained through semi-structured interviews, group interviews and observations were analysed by means of conceptual (thematic) analysis.

\subsubsection{Limitations}

A limitation to the study lies in the accessibility of the mining sector as research setting. Past research has shown that it is sometimes extremely difficult to interview employees and representatives of mining companies and to get their members to fill in questionnaires. It was not an easy task to gain access to the mining companies. Several visits and correspondence took place before permission was granted for the research. In addition, the platinum mine experienced many difficulties and labour unrest during the time the research was conducted. Because of that, several interviews with management were postponed and eventually cancelled. Despite numerous attempts from the researcher, no quantitative responses (questionnaires) were received from the management target group of the platinum mine. Furthermore, not all participants targeted for the semi-structured interviews and group interviews turned up for the meetings. Some of the participants could not stay for the duration of the interviews due to work responsibilities and emergencies. Others were drained and tired after shift work and wanted to depart for home as soon as possible to get some rest and take care of their family responsibilities before the start of their next shift. The researcher made use of existing skills, knowledge and networks to overcome some of these problems.

\section{Empirical Findings}

\subsection{Descriptive statistics}

Indicator statements on workplace opportunities were developed to verify whether women feel empowered to do their jobs effectively. Furthermore, the indicators aimed to determine whether mining companies are taking women seriously in the workplace and providing opportunities for further development of women in the core business of mining. The findings in terms of the indicator statements are presented below differentially in terms of the three mines included in the study.

Table 2: Participants' perceptions regarding workplace opportunities in the workplace

Indicator statement

\begin{tabular}{|c|c|c|c|c|c|c|c|c|}
\hline \multirow[b]{2}{*}{ Indicator statement } & \multicolumn{3}{|c|}{$\begin{array}{l}\text { Copper } \\
\text { mine }\end{array}$} & \multicolumn{3}{|c|}{$\begin{array}{l}\text { Phosphate } \\
\text { mine }\end{array}$} & \multicolumn{2}{|c|}{$\begin{array}{l}\text { Platinum } \\
\text { mine }\end{array}$} \\
\hline & 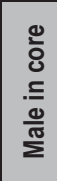 & 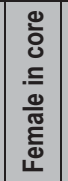 & 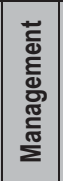 & 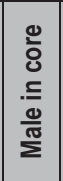 & 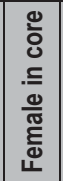 & 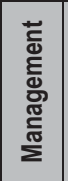 & 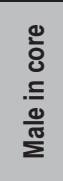 & 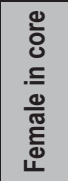 \\
\hline \begin{tabular}{|l|l|} 
1. & The mining company makes provision for skills development of women
\end{tabular} & 3.41 & 2.72 & 3.38 & 3.29 & 2.67 & 3.58 & 2.53 & 2.27 \\
\hline 2. The mining company offers training to women on a regular basis & 3.29 & 2.52 & 3.31 & 3.12 & 2.52 & 3.67 & 2.33 & 2.05 \\
\hline 3. The mining company provides specialised training to enable women to move into more technical areas of work & 3.11 & 2.33 & 3.19 & 3.07 & 2.45 & 3.00 & 2.33 & 1.90 \\
\hline \begin{tabular}{|l|l|l} 
4. I (female employees) feel adequately trained to perform my (their) job(s) effectively \\
\end{tabular} & 2.94 & 2.97 & 3.00 & 3.13 & 3.42 & 3.42 & 2.38 & 2.86 \\
\hline $\begin{array}{l}\text { 5. } \begin{array}{l}\text { The training programmes help to increase chances of promotions for women (e.g. to move from lower- } \\
\text { level jobs into better jobs within the mining company) }\end{array}\end{array}$ & 3.11 & 2.43 & 3.19 & 3.25 & 2.76 & 3.33 & 2.67 & 2.62 \\
\hline \begin{tabular}{|l|l} 
6. & The mining company makes provision for career development of women
\end{tabular} & 3.06 & 2.57 & 3.25 & 3.25 & 2.76 & 3.42 & \begin{tabular}{|l|}
2.53 \\
\end{tabular} & 2.29 \\
\hline 7. The mining company makes provision for women to enter managerial positions & 3.24 & 2.29 & 3.13 & 3.13 & 2.65 & 3.58 & 2.20 & 2.14 \\
\hline
\end{tabular}

Source: Constructed by author (2013) 
From the results it is evident that discrepancies exist between the data obtained from the three mines as well as from the various target groups within the mines.

Copper mine. According to the quantitative responses, a vast majority of the participants of the target groups management and men working in core mining positions of the copper mine positively responded to the indicators. The means calculated for these target groups for almost all the statements in this section are above 3 (see Table 2). These responses are clearly contradictory to responses obtained from the female participants working in core mining positions. The only positive responses were obtained for the following two indicators: The mining company makes provision for skills development of women (mean=2.72) and Female employees feel adequately trained to perform their jobs effectively (mean=2.97). Furthermore, low responses were obtained for the following two indicators: The mining company offers training to women on a regular basis (mean=2.52) and The mining company makes provision for career development of women (mean=2.57). Negative responses were obtained for the rest of the indicators. These statements calculated a mean of 2.5 and below, indicating that compliance with these statements are none or very limited.

Phosphate mine. More or less the same results were obtained from the male and management participants of the phosphate mine for indicators on Workplace opportunities (see Table 2). More than two-thirds of the participants agreed to strongly agreed with each of the indicators. All the statements calculated a mean above 3 . The female participants working in core mining positions reacted positively to most of the indicators (almost all the statements calculated a mean above 2.5), with the exception of the following indicators: The mining company offers training to women on a regular basis (mean=2.52) and The mining company provides specialised training to enable women to move into more technical areas of work (mean=2.45). These statements calculated a mean of 2.5 and below and could point towards a problem area.

Platinum mine. The responses obtained from the male participants working in core mining activities of the platinum mine were clearly contradictory to the responses obtained from the same target group of the copper and phosphate mines. However, agreement in responses was found between the two target groups (male and female participants working in core mining activities) of the platinum mine (see Table 2). Negative responses were reported for almost all the different indicators on Workplace opportunities. These statements calculated a mean of 2.5 and lower, indicating that compliance with these specific statements is none or very limited. The only positive response received from both target groups was for the following indicators: The training programmes help to increase chances of promotions for women (for example to move from lower-level jobs into better jobs within the mining company). This statement calculated a mean of above 2.5 .

\subsection{Factor analysis}

A factor analysis was conducted of the seven indicator statements pertaining to Workplace opportunities to explore the factorial structure of the section. The results of the KMO and Bartlett's test of sphericity are presented in Table 3.

Table 3: KMO and Bartlett's test of sphericity

\begin{tabular}{|ll|r|}
\hline KMO and Bartlett's test of sphericity & \multicolumn{1}{c|}{ Value } \\
\hline \hline KMO & & 0.870 \\
\hline P-value of Bartlett's test of sphericity & Approx. chi-sq & 451.840 \\
& df & 21 \\
& Sig. & 0.000 \\
\hline
\end{tabular}

Source: Constructed by author (2013)

The KMO measured 0.870 and indicates that the sample size is adequate for factor analysis. The p-value of Bartlett's test of sphericity returned a value smaller than 0.05 , suggesting that the correlation between statements is sufficient for factor analysis (Field, 2005:652). The results of the factor analysis are reported in Table 4. 
Table 4: Pattern matrixa.

\begin{tabular}{|l|c|c|}
\hline \multicolumn{1}{|c|}{ Question statement } & \multicolumn{1}{c|}{ Factor 1 } & Communalities \\
\hline No. & Workplace opportunities & 0.720 \\
\hline \hline D6 The mining company makes provision for career development of women & 0.848 & 0.711 \\
\hline D3 $\begin{array}{l}\text { The mining company provides specialised training to enable women to move into more } \\
\text { technical areas of work }\end{array}$ & 0.843 & 0.645 \\
\hline D1 The mining company makes provision for skills development of women & 0.803 & 0.593 \\
\hline D2 The mining company offers training to women on a regular basis & 0.770 & 0.565 \\
\hline D7 The mining company makes provision for women to enter managerial positions & 0.752 & 0.467 \\
\hline D5 The training programmes help to increase chances of promotions for women (e.g. to & 0.683 & 0.174 \\
\hline move from lower-level jobs into better jobs within the mining company) & 0.417 \\
\hline $\begin{array}{l}\text { Cronbach's alpha } \\
\text { Factor mean }\end{array}$ & $\mathbf{0 . 8 9}$ \\
\hline Factor standard deviation & $\mathbf{2 . 6 8}$ \\
\hline
\end{tabular}

Source: Constructed by author (2013)

Only one factor was extracted by Kaiser's criteria (Field, 2005:652) that explains $55.35 \%$ of the total variance in the section on Workplace opportunities. The statements all loaded above 0.4 on the identified factor. The communalities for all the questions are above 0.4, except for Question D4, which is 0.174 .

The factor mean calculated at 2.68, just above the required 2.5 , which indicates that a slight majority of the participants positively agreed with the factor and its statements. The factor shows good reliability with a Cronbach's alpha coefficient of 0.89 , which is well above the required 0.7 , and shows high reliability and internal consistency.

\subsection{Comparison of the three target groups of the different mines regarding workplace opportunities}

The descriptive statistics together with effect sizes of the different target groups regarding the section on Workplace opportunities are reported in Table 5 below.

Table 5: Comparison of the three target groups of the different mines regarding Workplace opportunities

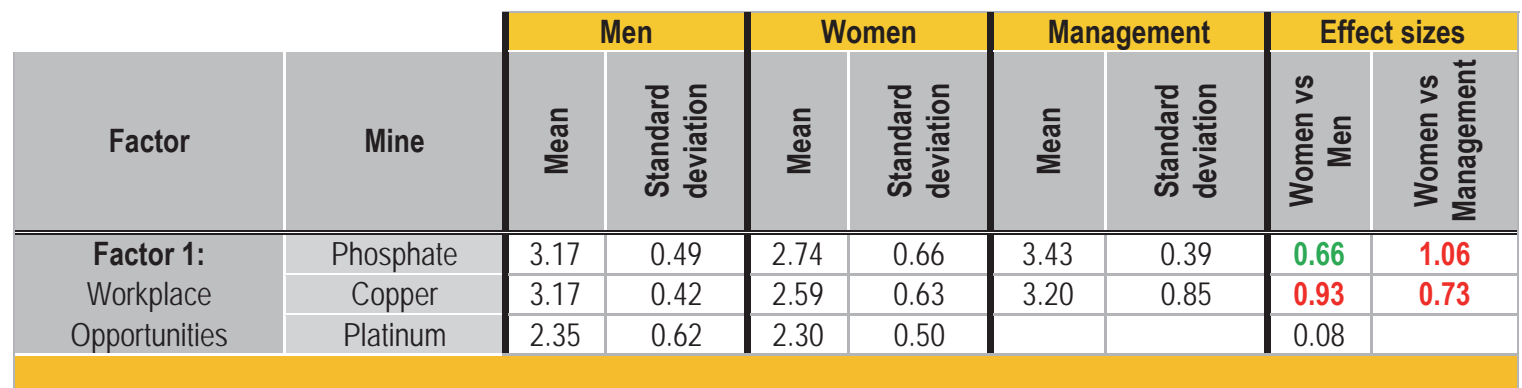

(a) small effect: $d=0.2$, (b) medium effect: $d=0.5$ and (c) large effect: $d=0.8$

Source: Constructed by author (2013)

It is evident from Table 5 that the effect sizes of the female versus male target group of the platinum mine for the Workplace opportunity factor are smaller than 0.2 , indicating that the difference between the means of the different target groups has a small effect and is not practically significant. The means for both target groups calculated below 2.5, indicating that compliance with the indicator statements contained in this factor is none or very limited. It could be understood that both target groups are in agreement that women are not provided with adequate opportunities for development in the core business of mining in the platinum mine. 
The d-value of the female versus male target groups of the phosphate mine shows that the difference between the means of these target groups has a medium effect (0.66). A large effect is evident from the three target groups of the copper mine as well as from the female versus management target group of the phosphate mine, as the d-value calculated larger than 0.73 . It could therefore be deducted that on average, the participants of the male target group of the phosphate mine as well as the management target groups of the phosphate and copper mines (as well as the male participants of the copper mine) are more in agreement with Workplace opportunities than the female target group themselves. They therefore believe that women are provided with adequate opportunities for development in the core business of mining, while this view is not supported by the majority of the participants of the female target group.

\subsection{Main concerns regarding workplace opportunities}

Data obtained from the qualitative inquiry yielded similar results to the quantitative data. From the interviews it was evident that much still needs to be done in terms of skills and career development and progression of women working in the core business of mining. The following main concerns were raised:

\subsubsection{Perceptions}

The perception still exists that mining is a man's environment; therefore, the participants felt that skills and career development opportunities are more inclined towards male employees. On the other hand, the male participants were of the opinion that women have more opportunities than men due to the fact that mining companies are forced to employ $10 \%$ women in the core business of mining. These different viewpoints are one of the major causes of frustration in the workplace. The following comments were made by some participants in this regard:

I feel skills development programmes are only provided for male employees.

They prefer to send men for skills development. Like for instance, there was this apprenticeship. They didn't give one to a single woman. They took 10 guys, without a woman there. It's difficult for me to progress to the next level.

\subsubsection{Recognition}

A serious need for recognition was expressed. Female employees want to be taken seriously in the mining workplace; they want to be heard. Furthermore, the participants indicated a need for approval of women's innovative ideas. They also voiced the opinion that more women should be involved in decision-making processes and should be appointed in management positions, such as shift bosses. The following quotation provide an indication of women's opinions regarding Recognition:

Even that woman who is a miner, she fought to be a miner, it was not easy for her to get through there, she had to fight, it was not a promotion ... they never believe in us that we can do a better job or the same job that men can do.

\subsubsection{Lack of training opportunities}

It is evident from the quantitative data that, although on average the management participants of mining companies positively indicated that adequate training opportunities are provided to women employed in core mining positions, this sentiment is not shared by a large number of the female participants (see Table 2). Data obtained from the qualitative inquiry revealed similar results. From the viewpoints expressed in interviews conducted with the female participants working in core mining positions, it was evident that most women want to develop their careers in the mining industry but find it difficult to get adequate support from mining companies. They voiced the opinion that they often have to use their own time for studies, training opportunities are not transparent and communicated to all employees and bursaries are not easily available. Furthermore, it is indicated that female employees are often appointed in certain positions of which they do not necessarily meet the requirements. Others admitted that they do receive on-the-job training and are able to do the work that they are appointed for, but were not sent on training to formally acquire the necessary qualifications. A strong need is expressed for opportunities to obtain formal qualifications. The participants also reported that they do not know with whom to discuss their training needs. A need was detected for clear and effective guidance (an approachable person to assist employees with their training needs). An example of women's needs in terms of training opportunities are illustrated in the following comment:

The mining company does not provide for career development of women, if I want to be trained in something, it should be done on my own. I want to be supported in the following ways: I would like the mining company to assist me 
with my studies, to provide bursaries and to provide me with a career development programme and plan.

\subsubsection{Lack of an effective mentoring system}

A lack of an effective mentoring system within the mining companies included in the study was also indicated. The participants indicated that more exposure to mentors would assist with career development, as illustrated in the following quotation:

I intend to develop my career in mining, but the mining company does not provide clear steps for career development. A good mentoring system as well as exposure to mentors will assist with career development.

\subsubsection{Lack of career guidance}

Furthermore, the female participants expressed a need for career guidance in terms of the following:

Career development programmes should be in place. be clear.

Career paths should be transparent. Specific steps to be taken in order to progress in the mining company should

Career development opportunities should be communicated and available to all employees.

Communication lines should be clear. A need was expressed for an approachable person to contact and assist employees with career development.

Women's needs in terms of career guidance are clearly noted in the following comment:

Career paths will definitely assist women in making progress in their careers. We know what we want to achieve, but we don't know the steps to get there. We see the goal, but don't know the tools and techniques to achieve these goals.

\subsubsection{Financial support}

Although some participants indicated that mining companies do provide financial support, others expressed a serious need for financial support, as mentioned in the remarks below:

Would like support from the mining company in the form of training and financial support.

To get a bursary at the mine is very difficult. Most of the people that are studying, they are financing themselves.

\subsubsection{External appointments}

One of the main concerns raised by the female participants was the tendency of mining companies to rather employ persons from outside the mine to fill positions within companies than to develop their own personnel. This leads to much frustration on the side of women employed in core positions. The following comments were made in this regard:

The mining company also employ women from outside and rather send them for skills development. It's difficult for me to progress to the next level.

The only thing that our company is doing is to take women from outside and put them in here, while we are here they don't train us, they don't do anything. It is difficult for us to go to the next level. They don't develop us, they just dump us there. We end up growing old there. They are not doing much for women.

\subsubsection{Management response to qualitative inquiry}

Although the above concerns were raised by the female participants working in core mining activities across all three mines, the mining companies included in the study already started to show a commitment to the transformation agenda of the democratic regime by starting to implement strategies to develop women in the core business of mining. The management participants indicated that certain programmes are already in place to fulfil in the training and developmental needs of women employed in core mining positions. However, it was clear that some mines are progressing faster than others. The following initiatives are provided by the mines included in the study, among others:

- Study assistance in the form of bursaries (also for employees' dependents), learnerships, opportunities to obtain formal qualifications at an institution of higher learning and graduate development programmes; 
- $\quad$ ABET training for illiterate people;

- Mentorship schemes;

- Career development plans;

- Job descriptions, indicating the requirements to progress to the next level.

Furthermore, two of the mines included in the study indicated that Grade 12 has also become a requirement to apply for a position at the mining company. In addition, one of the mines indicated that science as a school subject has also become a prerequisite for employment at the mining company. The following two main reasons were put forward for increased admission requirements. Firstly, it is determined by the nature of the work and secondly, it is done to build the overall skills level of the business. According to the participants, a large number of workers in the mining industry are still illiterate. This hinders workers' opportunities to be promoted. The illiterate person will, probably for the rest of his/her life, remain on the same level. One of the participants highlighted the effect that continuous illiteracy has by stating:

The implication is that companies become poorer and poorer in terms of internal promotion opportunities and these opportunities are then taken up by external candidates. It is bad for the organisation, it is bad for the morale of the workers, because people sit there for 20 years and are still employed at the lowest level.

Although the above-mentioned programmes are in place at the mining companies, it is evident from the findings that female employees are not fully aware of the programmes. A need for transparency on the side of management was detected among participants.

\section{Discussion}

The quantitative results indicated that only a limited number of female participants working in core mining activities of the copper and platinum mine positively agreed with the Workplace opportunities factor and its statements, thereby indicating a perception that female employees are not provided with adequate workplace opportunities. This view was not supported by the majority of the male and management participants of the copper mine. The d-value of the female versus male $(d=0.93)$ and female versus management $(d=0.73)$ target groups of the copper mine shows that the difference between the means of these target groups has a large effect. The results also showed that the majority of the female participants working in core mining activities of the phosphate mine are generally satisfied with the workplace opportunities provided. Although a large effect is evident from the $d$-value $(d=1.06)$ of the female versus management target group of the phosphate mine, both means calculated well above 2.5 , indicating that compliance with the statements contained in the factor is satisfactory. The qualitative findings revealed a need for recognition, more training opportunities, an effective mentoring system, proper career guidance, financial support and a development programme for internal employees. The above findings are also in line with the findings of the impact assessment done by the Department of Mineral Resources in 2009 which revealed a definite lack of investment in core and critical skills development in the mining sector. Furthermore, the findings indicated that career plans (paths) are more focussed on the development of senior managers and mostly exclude lower-level employees. These findings are also supported by the literature review which suggests that, globally, women face challenges with regard to insufficient professional and career development, which include poor mentoring systems and career paths.

It is evident from the empirical findings that some mining companies are progressing faster than others with regard to development and mainstreaming of women in core positions. Although women's participation in the mining labour force has increased over the years, women's position, development and advancement in the workplace continue to be subordinate to that of their male counterparts. It is evident that despite various equal employment opportunity legislation and policies, many hidden barriers still exist and prevent women from advancement in the industry. There is still a long way to go to effectively break down barriers and to ensure women's full participation in the global mining labour force. Mining companies need to be aware of female employees' needs in terms of training, skills and career development. The Mining Charter as well as the requirements of the Social and Labour Plan obliged mining companies to develop and implement a comprehensive human resource development programme that should provide for a detailed skills development, mentorship, bursary and internship plan. Adequate and transparent workplace opportunities, which include training and skills development opportunities, career development opportunities (for example mentorships, career paths and career guidance) and financial assistance (for example bursaries) will not only contribute towards a skilled workforce, but will also empower women to do their work effectively and could enhance productivity, personal satisfaction and job enrichment (Nel et al., 2012:380). The development and mainstreaming of women in the core business of mining is critical for reaching employment targets, as prescribed by the Mining Charter, as well as for retaining women for the mining industry. 


\section{Conclusion and Recommendations}

It is evident from the quantitative results as well as the qualitative findings that much still needs to be done on the side of mining companies in terms of the provision of adequate training opportunities and suitable and transparent skills and career development programmes. Although positive results (quantitative) were obtained from the majority of the participants of the management target groups of the respective mines, this view was not supported by the majority of the female participants. The qualitative findings revealed further specific concerns that should be taken in to account to ensure development, progression and mainstreaming of women in the core business of mining. The following recommendations, informed by the literature review and empirical findings, are made to address concerns regarding workplace opportunities for women employed in core mining activities and to contribute to the sustainable deployment of women in the mining sector:

- Mining companies should adhere to the requirements of the EEA, the SDA as well as the revised Mining Charter. Mining companies should provide a detailed skills development plan, career development matrices of each discipline, individual development plans for employees, mentorship plans for employees as well as a bursary and internship plans in their Social and Labour Plans. The implementation and operationalisation of the above-mentioned plans are vital.

- Practices, such as career counselling, assisting with childcare, creating a healthy work environment and access to supportive and challenging mentors, as suggested by Stead and Watson (2010:120), could also contribute to removing career development barriers for women in the mining workplace.

- Career counselling could include the following: identifying women's strengths, assisting in confronting myths and stereotypes in the workplace, learning of negotiation skills, assisting in balancing home and work responsibilities, preparing women to handle sexual harassment in the workplace, setting up specific support groups for women, and so forth (Stead and Watson, 2010:120).

\section{References}

Archer, J., \& Lloyd, B. (2002). Sex and gender. Cambridge: Cambridge University Press.

Babbie, E., \& Mouton, J. (2011). The practice of social research. Cape Town: Oxford University Press Southern Africa.

Department of Labour. (2012). 12th Commission of Employment Equity annual report. [Online] Available: http://www.info.gov.za/view/ DownloadFileAction?id=174047 (March 15, 2013).

Department of Mineral Resources. (2009). Mining Charter impact assessment report. [Online] Available: http://www.dmr.gov.za/... minerals...charter...miningcharterimpact.2009/0.htm (September 13, 2010).

Field, A. (2005). Discovering statistics using SPSS. London: Sage.

Field, A. (2009). Discovering statistics using SPSS. London: Sage.

Harmony Gold Mining Company. (2008). Harmony sustainable development report. [Online] Available: www.har.co.za/files/Harmony_ SD2008.pdf (October 20, 2009).

Hermanus, M.A. (2007). Women in mining in South Africa. [Online] Available: http://www.csmi.co.za/cp/cp_2007.asp (January 12, 2012).

Lahiri-Dutt, K. (2011). Gendering the field: towards sustainable livelihoods for mining communities. [Online] Available: http:/lepress.anu. edu.au/gendering_field_citation (February 25, 2012).

Lorber, J. (2010). Gender inequality: feminist theories and politics. New York: Oxford University Press.

Minerals Council of Australia. (2011). Unearthing new resources: attracting and retaining women in the Australian minerals industry. [Online] Available: www.minerals.org.au/file_upload/files/.../unearthing_new_resources.pdf (February 25, 2012).

Moyo, T. (2010). Extractive industries and women in South Africa. BUWA! - a journal on African women's experiences. [Online] Available: http://www.osisa.org/buwa/regional/women-and-extractive-industries-southern-africa (February 2, 2012).

Nel, P.S., Kirsten, M., Swanepoel, B.J., Erasmus, B.J. \& Poisat, P. (2012). South African employment relations: theory and practice. Pretoria: Van Schaik.

Pattenden, C. (1998). Women in mining: a report to the "Women in Mining" Taskforce. The Australasian Institute of Mining and Metallurgy. [Online] Available at: https://www.ausimm.com.au/content/docs/wimreport.pdf (February 25, 2012).

Pons, A. \& Deale, P. (2010). Labour relations handbook. Cape Town: Juta.

Republic of South Africa. (1996). Constitution of the Republic of South Africa Act, No. 108 of 1996. Pretoria: Government Printers.

Republic of South Africa. (1998). Employment Equity Act, No. 55 of 1998. Pretoria: Government Printers.

Republic of South Africa. (2002). Mineral and Petroleum Resources Development Act, No. 28 of 2002. Pretoria: Government Printers.

Republic of South Africa. (2004). Broad-based Socio-economic Empowerment Charter for the South African Mining Industry. Notice No. 1639 of 2004. Government Gazette, 25899:6-17, 13 August.

Republic of South Africa. (2010a). Amendment of the Broad-based Socio-economic Empowerment Charter for the South African Mining and Minerals Industry. [Online] Available: http://www.dmr.gov.za/publications/summary/108-mining-charter-downloads/128amendedofbbseecharter.html (June 27, 2013). 
Republic of South Africa. 2010b. Revised Social and Labour Plan Guidelines. [Online] Available: www.dmr.gov.za/guidelines-revisedsocial-and-labour-plans.html (July 2, 2013).

Robbins, S.P., Judge, T.A., Odendaal, A. \& Roodt, G. (2009). Organisational behaviour: global and South African perspectives. Cape Town: Pearson Education South Africa.

South African Institute of Race Relations. (2012). Fast facts. [Online] Available: http://www.sairr.org.za (April 22, 2013).

Stead, G.B. \& Watson, W. (2010). Career psychology. Pretoria: Van Schaik.

Wharton, A.S. (2006). The sociology of gender: an introduction to theory and research. Oxford: Blackwell.

Women in Mining Canada. (2010). Ramp-Up: a study on the status of women in Canada's mining and exploration sector. [Online] Available: 0101.nccdn.net/1_5/1f2/13b/0cb/RAMP-UP-Report.pdf (February 25, 2012). 